\title{
PENGUATAN KARAKTERISTIK DAN KOMPETENSI KEWIRAUSAHAAN UNTUK MENINGKATKAN KINERJA UMKM
}

\author{
Endang Dhamayantie ${ }^{(1)}$ \\ Rizky Fauzan (2) \\ (1),(2)Fakultas Ekonomi dan Bisnis, Universitas Tanjungpura \\ email: edhamayantie@yahoo.com
}

\begin{abstract}
ABSTRAK
Karakteristik dan kompetensi kewirausahan merupakan dua fakor penting yang diperlukan pelaku Usaha Mikro, Kecil, dan Menengah (UMKM) untuk menghadapi tantangan lingkungan dalam dunia bisnis yang dinamis dan mencapai kinerja bisnis tinggi. Penelitian ini bertujuan untuk menguji pengaruh karakteristik kewirausahaan dan kompetensi kewirausahaan terhadap kinerja UMKM. Penelitian dilakukan pada UMKM di Kabupaten Kubu Raya. Sampel penelitian sebanyak 184 UMKM yang ditentukan melalui metode purposive sampling. Data dikumpulkan melalui survei dengan penyebaran kuesioner. Teknik analisis data menggunakan model persamaan struktural dengan pendekatan Partial Least Square (PLS). Hasil penelitian menunjukkan bahwa karakteristik kewirausahaan berpengaruh positif signifikan terhadap kompetensi kewirausahaan, namun karakteristik kewirausahaan tidak berpengaruh signifikan terhadap kinerja UMKM dan kompetensi kewirausahaan berpengaruh positif signifikan terhadap kinerja UMKM.Hasil penelitian juga mengindikasikan bahwa kompetensi kewirausahaan memediasi penuh hubungan antara karakteristik kewirausahaan dan kinerja UMKM.
\end{abstract}

Kata Kunci: karakteristik kewirausahaan, kompetensi kewirausahaan, kinerja UMKM

\begin{abstract}
Entrepreneurial characteristics and competencies are two important factors needed by entrepreneur Micro, Small and Medium Enterprises (SMEs) to face the environmental challenges in the dynamic world of business and achieve high business performance. This study aimed to examine the effect of the entrepreneurial characteristics and entrepreneurial competencieson SMEs performance. The study was conducted on SMEs in Kubu Raya. The research sample is 184 SMEs were determined through purposive sampling method. Data were collected through a survey with questionnaires. Data were analyzed using structural equation modeling with Partial Least Square (PLS) approach. The results showed that entrepreneurial characteristics have significant positive effect on entrepreneurial competencies, but entrepreneurial characteristics have not significant effect on the SMEs performance and entrepreneurial competencies have significant positive effect on the performance of SMEs. The results also indicate that entrepreneurial competence full mediation the relationship between entrepreneurial characteristics and SMEs performance.
\end{abstract}

Keywords: entrepreneurial characteristics, entrepreneurial competencies, SMEs performance

\section{PENDAHULUAN}

Usaha Mikro, Kecil, dan Menengah (UMKM) merupakan sektor yang amat vital sebagai penyangga ekonomi daerah dalam menciptakan pertumbuhan dan lapangan pekerjaan. Namun, pentingnya sektor ini belum diimbangi dengan kontribusi terhadap nilai Produk Domestik Bruto (PDB) dan nilai ekspor yang relatif masih rendah bila dibandingkan dengan populasi pelaku UMKM sebanyak 99,9\% (Bank Indonesia, 2015). Kondisi ini tidak terlalu mengejutkan, karena banyak studi maupun data nasional menunjukkan kinerja UMKM relatif buruk dibandingkan dengan usaha besar, bahkan dengan UMKM di negara maju (Tambunan, 2012). Demikian juga hasil kajian Pusat Inovasi
MKM APEC tentang daya saing global UMKM di 13 negara termasuk Indonesia,menunjukkan bahwa Indonesia termasuk negara yang UMKM-nya berdaya saing rendah dibandingkan negara ASEAN lainnya seperti Singapura, Malaysia, Thailand, dan Filipina (Susilo, 2010).

Rendahnya kinerja yang dihasilkan UMKM di Indonesiadisebabkan rendahnya kualitas sumber daya manusia (SDM) (Dipta, 2012) atau dengan kata lain rendahnya kompetensi kewirausahaan (Susilo, 2010).Hal ini ditunjukkan dengan masih rendahnya pengembangan dan penguasaan ilmu pelaku UMKM dibidang manajemen, organisasi, teknologi, pemasaran dan kompetensi lainnya yang diperlukan dalam mengelola usaha.Terlebih lagi spirit 
kewirausahaannya.Selain itu, kultur UMKM yang tidak profesional menjadi kendala tersendiri bagi peningkatan kualitas SDM. Disamping kondisi yang dihadapi oleh UMKM dengan latar belakang pendidikan pelaku UMKM rendah, sehingga sulit memahami atau menguasai tentang cara meningkatkan kualitas dan standarisasi produk, memperluas dan meningkatkan akses pembiayaan, memperkuat dan meningkatkan akses teknologi untuk pengembangan UMKM, meningkatkan akses promosi di dalam dan luar negeri, dan membangun jejaring bisnis global.

Rendahnya kualitas SDM memberikan dampak terhadap rendahnya kinerja UMKM.Padahal SDM merupakan salah satu faktor utama dalam menentukan tingkat daya saing usaha untuk menghadapi perubahan lingkungan bisnis yang cepat, perdagangan bebas ASEAN-China (ACFTA), dan pasar tunggal ASEAN melalui Masyarakat Ekonomi ASEAN (MEA).SDM pada UMKM terutama pengusaha atau pemilik merupakan penggerak utama perusahaan.Kreativitas, jiwa kewirausahaan, dan jiwa inovatif dari pengusaha yang didukung oleh keahlian atau keterampilan para pekerja adalah sumber utama peningkatan daya saing UMKM (Susilo, 2010).Pelaku UMKM harus menjadi motor penggerak meningkatkan daya saing usahanya.

Keberhasilan kinerja bisnis usaha kecil ditentukan oleh faktor individual dan faktor lingkungan (Attahir, 1995). Khusus untuk faktor individual, pelaku usaha harus memiliki karakteristik kewirausahaan yang baik dan kompetensi tertentu. Karakteristik kewirausahaan yang telah diuji hubungannya dengan kinerja usaha diklasifikasikan kedalam beberapa tipe ( $\mathrm{Li}, 2009)$, yaitu karakteristik demografi (gender, umur, etnis, dan latar belakang orang tua), karakteristik psikologis dan perilaku (motivasi, atribut personal, nilai, tujuan, dan sikap), dan karakteristik human capital (pendidikan, pengalaman, pelatihan, keterampilan dan pengetahuan teknis). Karakteristiktersebut mencakup sifat-sifat kepribadian dan kompetensi individual dalam proses kewirausahaan yang akan mempengaruhi kinerja bisnis UMKM. Untuk itu, pelaku UMKM sedapat mungkin dituntut untuk dapat menerapkan jiwa kewirausahaan dalam mengendalikan usahanya untuk meningkatkan daya saing dan mempertahankan usahanya dari kegagalan (Zulfadil, 2006) dan mendayagunakan kompetensinya agar berhasil. Temuan Sarwoko et al. (2013) mengindikasikan jika pelaku usaha kecil memiliki karakteristik dan kompetensi kewirausahaan makaakan berdampak pada pencapaian kinerja usaha.
Seseorang dapat berlaku seperti karakteristik kewirausahaan antara lain percaya diri, berorientasi tugas dan hasil, pengambilan resiko, kepemimpinan, keorisinilan, dan berorientasi masa depan, tetapi hanya orang yang bersifat wirausaha yang mampu bertindak menggunakan karakteristik tersebut dalam pekerjaannya (Meredith et al., 2000). Hasil-hasil penelitian sebelumnya menunjukkan bahwa karakteristik kewirausahaan dapat meningkatkan kinerja dan kesuksesan bisnis pada usaha kecil di Inggris (Hall, 1994), UKM di Bangladesh (Islam et al., 2011), dan UKM di Indonesia (Sarwoko et al., 2013). Karakteristik kewirausahaan juga mampu meningkatkan optimisme wirausaha di Amerika (Liang \& Dunn, 2010). Karakteristik wirausaha yang optimis, bahkan dalam situasi yang buruk, merupakan faktor penting dalam mendorong kesuksesan (Kuratko \& Hodgetts, 2004). Karakteristik kewirausahaan yang tinggi berhubungan positif dengan kesuksesan usaha (Ardichvili et al., 2003). Namun, hasil penelitian Begley \& Boyd (1987) menunjukkan hubungan rendah antara karakteristik kewirausahaan dan kinerja finansial usaha kecil di Inggris.Berdasarkan kajian teori dan empiris, maka hipotesis dalam penelitian ini adalah karakteristik kewirausahaan berpengaruh positif terhadap kinerja UMKM (Hipotesis 1).

Karakteristik kewirausahaan seperti sifat-sifat individu wirausaha (motivasi, niat, dan pengalaman) juga dapat menjadi faktor yang mempengaruhi kompetensi kewirausahaan (Segal et al., 2009). Pemahaman tentang karakteristik kewirausahaan diperlukan untuk menilai kompetensi teknikal dan manajerial dalam memulai, mengembangkan dan keberlanjutan usaha kecil (Adegbite et al., 2006). Hasil penelitian Sarwoko et al. (2013) menunjukkan terdapat pengaruh positif signifikan antara karakteristik kewirausahaan dengan kompetensi wirausaha. Hipotesis dalam penelitian ini adalah karakteristik kewirausahaan berpengaruh positif terhadap kompetensi kewirausahaan (Hipotesis 2).

Kompetensi kewirausahaan diperlukan dalam menghadapi persaingan secara lokal dan global (Ng $\&$ Kee, 2013). Kompetensi wirausaha menjadi lebih utama dalam rangka mengambil langkah proaktif terhadap tantangan lingkungan bisnis. Hal ini dikarenakan pemilik usaha kecil umumnya bertindak sebagai manajer, pengelola dan juga pemimpin usaha yang memimpin usaha dan memimpin manusia (Zimmerer \& Scarborough, 2004), sehingga kompetensi sebagai manajer yang mencakup perencana, pengorganisasi, administrator, dan komunikator diperlukan untuk meningkatkan kinerja 
usaha mereka (Cyhe et al., 2010). Sifat kompetensi wirausaha mengindikasikan sebagai konsep penting untuk meningkatkan kewirausahaan (Wickramaratne et al., 2014). Dengan kata lain, kompetensi manajerial pelaku wirausaha memainkan peran yang semakin signifikan dalam kesuksesan UMKM.

Boyatzis (2009) mendefinisikan kompetensi sebagai sebuah kapabilitas atau kemampuan. Menurut Kaur\&Bains (2013), kompetensi adalah sejumlah pengalaman, pengetahuan, keterampilan dan sikap yang diperlukan selama hidup untuk keefektifan kinerja dalam tugas atau pekerjaan. Spencer \& Spencer (1993:9) mendefinisikan kompetensi sebagai karaktersitik yang mendasar pada setiap individu yang dihubungkan dengan kriteria yang direferensikan pada kinerja yang efektif dan/atau unggul dalamsebuah pekerjaan atau situasi.Sementara Baum et al. (2001) menjelaskan kompetensi sebagai karakter individual seperti pengetahuan, keterampilan, dan kemampuan yang diperlukan untuk melakukan pekerjaan tertentu. Kompetensi merupakan konsep yang berkaitan dengan pengetahuan, keterampilan dan kemampuan seseorang untuk mencapai kinerja.

Baum et al. (2001)memfokuskan pada dua kompetensi umum dan dua kompetensi khusus. Kompetensi umum mencakup keterampilan organisasi dan keterampilan peluang, sedangkan kompetensi khusus mencakup keterampilan industri dan keterampilan teknis. Kompetensi khusus (kompetensi industri dan teknis) harus menerima perhatian lebih dari peneliti dalam setting kewirausahaan karena hasil penelitian Baum et al. menunjukkan kompetensi khusus berpengaruh langsung signifikan terhadap pertumbuhan usaha (kinerja bisnis). Bahkan kompetensi khusus tersebut merupakan bentuk penting penguasaan keahlian yang memfasilitasi implementasi visi dan strategi wirausaha.

Menurut Ng dan Kee (2013), kompetensi yang harus dimiliki oleh UMKM idealnya adalah kompetensi wirausaha (fokus pada peluang bisnis dan penciptaan nilai), kompetensi manajerial (fokus pada manajemen manusia dan kompleksitas perencanaan, pengorganisasian, koordinasi dan pengawasan yang efektif), dan kompetensi teknikal (fokus pada ilmu dan teknologi, dan inovasi kebutuhan pelanggan). Kompetensi kewirausahaan menunjukkan kemampuan untuk mengamati lingkungan untuk memilih peluang menjanjikan dan memformulasi strategi, sementara kompetensi manajerial memerlukan keterampilan konseptual, interpersonal dan teknikal.
Man et al. (2002) mengidentifikasi enam bidang kompetensi utama yang harus dimiliki UKM, yaitu peluang, organisasi, strategi, relasi, komitmen, dan konseptual. Kompetensi peluang berhubungan dengan identifikasi dan pengembangan peluang pasar melalui berbagai cara. Kompetensi organisasi diakui sama dengan kompetensi manajerial, mencakup kemampuan memimpin, mengontrol, memonitor, mengorganisasi, dan mengembangkan sumber daya eksternal dan internal untuk menjamin kapabilitas perusahaan. Kompetensi strategi mencakup pengaturan, evaluasi, dan menjalankan strategi perusahaan.Kompetensi relasi menyangkut interaksi membangun kerjasama dan kepercayaan yang memerlukan kemampuan persuasif, komunikasi dan keterampilan interpersonal.Kompetensi komitmen sebagai kekuatan wirausaha untuk maju dalam bisnis.Kompetensi konseptual berhubungan dengan perilaku wirausaha seperti perpsektif jangka pendek, cepat menyelesaikan masalah, atau membutuhkan respon intuitif. Kompetensi kewirausahaan dipandang penting bagi pertumbuhan dan kesuksesan bisnis.

Menurut Man \& Lau (2005), kompetensi kewirausahaan memiliki dua sumber; pertama, komponen yang berakar dari latar belakang wirausaha (seperti sifat, kepribadian, sikap, citra diri, dan peran sosial) dan kedua, komponen yang dapat diperoleh pada pekerjaan atau melalui teori atau pembelajaran praktis (seperti keterampilan, pengetahuan, dan pengalaman). Man et al. (2002) menganggap kompetensi kewirausahaan sebagai karakteritik dengan tingkat yang lebih tinggi yang meliputi ciri-ciri kepribadian, keterampilan dan pengetahuan, dan karena itu dapat dilihat sebagai total kemampuan wirausaha untuk melakukan peran pekerjaan dengan sukses.

Kompetensi merupakan seperangkat faktorfaktor keberhasilan yang berkontribusi untuk mencapai kinerja tinggi dan hasil nyata (Wu, 2009). Hasil-hasil penelitian sebelumnya (Ardiana dkk, 2010; Barazandeh et al., 2015; Baum et al., 2001; Hormiga et al., 2010; Karami, 2004; Man \& Law, 2008; Mohamad \& Sidek, 2013; Sarwoko et al., 2013; Tanoira \& Valencia, 2014) mendukung bahwa kompetensi kewirausahaan dapat berkontribusi pada kinerja UMKM. Oleh karena itu dibutuhkan pelaku UMKM yang memiliki kompetensi memadai untuk meningkatkan daya saingnya.Berdasarkan kajian teori dan empiris maka hipotesis dalam penelitian ini adalah kompetensi kewirausahaan berpengaruh positif terhadap kinerja UMKM (Hipotesis 3). 
Kalimantan Barat sebagai pintu gerbang yang berbatasan langsung dengan negara tetangga Malaysia dan Brunei Darussalam memiliki peluang dan tantangan tersendiri bagi UMKM dalam menghadapi pasar global.Masih terdapat banyak skeptisisme atau keraguan dari sejumlah pihak mengenai kesiapan UMKM di Kalimantan Barat, khususnya Kabupaten Kubu Raya dalam menghadapi pasar global. Perkembangan jumlah UMKM di Kabupaten Kubu Raya belum diiringi dengan perkembangan dalam kinerjausaha yang bermuara pada keterbatasan SDM UMKM.Dalam Rencana Strategis 2014-2019 menunjukkan permasalahan yang meliputi UMKM antara lain masih lemahnya pengembangan karakteristik kewirausahaan dan rendahnya kompetensi (pengetahuan, keterampilan, dan kemampuan) SDM dalam manajemen usaha. Untuk itu perlu adanya upaya konkret yang harus menjadi perhatian baik pemerintah daerah, perguruan tinggi, stakeholders maupun pelaku UMKM sendiri dalammemanfaatkan liberalisasi pasar semaksimal mungkinuntuk meningkatkan kemampuan UMKM agar dapat menjadi UMKM yang kuat dan handal serta mampumenghadapi persaingan bisnis pasar global yang sangat kompetitif.

Upaya yang diperlukan untuk memperkuat atau memberdayakan UMKM agar tidak ketinggalan dengan pelaku usaha lain baik di dalam maupun di luar negeri dapat dilakukan melalui peningkatan karakteristik dan kompetensi kewirusahaan UMKM (Dipta, 2012). Melalui penguatan karakteristik dan kompetensi kewirausahaan diharapkan UMKM akan dapat meningkatkan kualitas dan standarisasi produk yang setara di kawasan ASEAN, memperluas dan meningkatkan akses pembiayaan UMKM, memperkuat dan meningkatkan akses teknologi untuk pengembangan UMKM, meningkatkan akses promosi di dalam dan luar negeri, membangun jejaring bisnis global, dan pada akhirnya mampu meningkatkan kinerja UMKM.

Berdasarkan latar belakang tersebut, untuk memahami keterkaitan karkateristik kewirausahaan dan kompetensi SDM dengan kinerja UMKM, maka perlu dilakukan penelitian yang menguji pengaruh antar variabel tersebut, sebagai dasar untuk merumuskan kebijakan strategis dalam pengembangan kewirausahaan UMKM di Kabupaten Kubu Raya. Hal ini dikarenakan karakteristik kewirausahaan dan kompetensi SDM merupakan fungsi bisnis potensial yang menjadi elemen kunci dari strategi setiap UMKM dalam usahanya membangun dan mempertahankan keunggulan kompetitif di pasar global.

\section{METODE PENELITIAN}

Pendekatan penelitian menggunakan penelitian kuantitatif dengan melakukan riset kausal untuk menguji keterkaitan karakteristik dan kompetensi kewirausahaan dengan kinerja UMKM.Variabel yang dianalisis meliputi variabel karakteristik kewirausahaan, kompetensi kewirausahaan, dan kinerja UMKM.

Karakteristik kewirausahaan, yaitu karakteristik yang melekat pada pelaku UMKM. Pengukuran karakteristik kewirusahaan berdasarkan pendapat Meredith et al. (2000) meliputi percaya diri, berorientasi tugas dan hasil, pengambilan resiko, kepemimpinan, keorisinilan, dan berorientasi masa depan. Kompetensi kewirausahaan, yaitu pengetahuan, keterampilan, dan kemampuan yang diperlukan pelaku UMKM untuk mencapai kinerja yang unggul. Pengukuran kompetensi kewirausahaan berdasarkan pendapat Baum et al. (2001) mencakup pengetahuan, keterampilan, dan kemampuan.Kinerja UMKM, yaitu keberhasilan atau kesuksesan UMKM dibanding tahun sebelumnya. Pengukuran kinerja UMKM terdiri dari empat indikator. Tiga indikator mengadopsi dari beberapa pendapat (Amage et al., 2014; Baum et al., 2001; Driessen \& Ende, 2006; dan Lee \& Tsang, 2001), yang terdiri dari pertumbuhan penjualan, pertumbuhan laba, dan pertumbuhan aset. Dilengkapi satu indikator lainnya, yaitu pertumbuhan pelanggan.

Semua variabel penelitian diukur dengan menggunakan skala Likert lima point dengan skala 1 = sangat tidak setuju dan 5 = sangat setuju. Kerangka konseptual penelitian ditunjukkan pada Gambar 1.

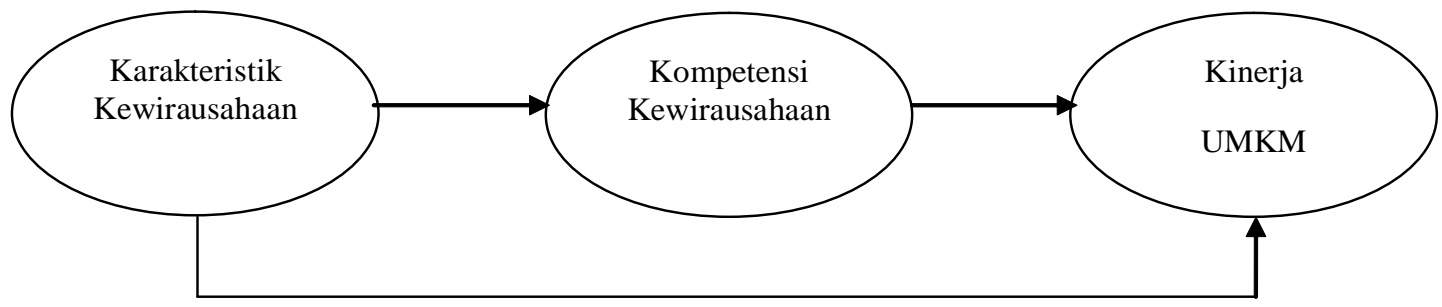

Gambar 1. Kerangka konseptual penelitian.

Sumber: Kajian konseptual dan empiris. 
Penelitian dilakukan terhadap pelaku UMKM di Kabupaten Kubu Raya Kalimantan Barat. Oleh karena jumlah UMKM belum terindentifikasi secara pasti, maka pemilihan sampel dilakukan dengan teknik purposive sampling dengan karakteristik usaha ekonomi produktif. Ukuran sampel yang direkomendasikan didasarkan pendapat Ghozali \& Latan (2015:51) dalam penggunaan metode partial least square (PLS) minimal 30-100 sampel, maka sampel penelitian sebanyak 250 .

Tabel 1. Hasil Uji Validitas

\begin{tabular}{llcc}
\hline \multicolumn{1}{c}{ Variabel } & \multicolumn{1}{c}{ Indikator } & Korelasi & Keterangan \\
\hline Karkatersitik & PercayaDiri & 0,684 & Valid \\
Kewirausahaan & OrientasiTugas dan Hasil & 0,814 & Valid \\
& Pengambilan Resiko & 0,739 & Valid \\
& Kepemimpinan & 0,814 & Valid \\
& Keorisinilan & 0,767 & Valid \\
& Orientasi Masadepan & 0,587 & Valid \\
\hline Kompetensi & Pengetahuan & 0,874 & Valid \\
Kewirausahaan & Keterampilan & 0,929 & Valid \\
& Kemampuan & 0,846 & Valid \\
\hline Kinerja Usaha & Penjualan & 0,917 & Valid \\
& Laba & 0,956 & Valid \\
& Aset & 0,923 & Valid \\
& Pelanggan & 0,819 & Valid \\
\hline
\end{tabular}

Sumber: Hasil pengolahan data penelitian

Teknik pengumpulan data melalui penyebaran kuesioner.Kuesioner yang disebar sudah diuji tingkat validitas dan reliabilitas melalui uji coba kuesioner terhadap 30 pelaku UMKM. Hasil pengujian validitas yang dilakukan dengan Pearson's Product Moment Corelation menunjukkan seluruh indikator penelitian valid dengan nilai korelasi di atas 0,5 dan tingkat signifikansi pada taraf 0,01 , sementara pengujian reliabilitasdengan Cronbach's Alpha menunjukkan masing-masing variabel reliabel dengan nilai koefisien alpha lebih besar dari 0,8. Tabel 1 dan Tabel 2 menunjukkan hasil uji validitas dan reliabiltas.

\section{Tabel 2. Uji Reliabilitas Variabel Penelitian}

\begin{tabular}{lcc}
\hline \multicolumn{1}{c}{ Variabel } & Koefisien Alpha & Keterangan \\
\hline Karakteristik kewirausahaan & 0,813 & Reliabel \\
Kompetensi kewirausahaan & 0,847 & Reliabel \\
Kinerja usaha & 0,923 & Reliabel \\
\hline
\end{tabular}

Sumber: Hasil pengolahan data penelitian

Model analisis data yang digunakan dengan pendekatan partial least square (PLS). PLS adalah structural equation modeling (SEM) berbasis component atau variance dan dapat digunakan untuk konfirmasi teori serta menjelaskan ada tidaknya hubungan antar variabel laten.

\section{HASIL DAN PEMBAHASAN}

Penelitian dilakukan terhadap pelaku UMKM di Kabupaten Kubu Raya dengan kriteria usaha ekonomi produktif dan memiliki tenaga kerja kurang dari 100 orang.Data penelitian dikumpulkan melalui survei dengan menyebarkan kuesioner sebanyak 250 buah.Dari 250 buah kuesioner yang disebar, 184 buah kuesioner yang kembali dan dapat diolah lebih lanjut.

Gambaran karakteristik responden meliputi jenis kelamin, usia, dan pendidikan terakhir ditunjukkan pada Tabel 3. Karakteristik responden tersebut menunjukkan jumlah pelaku UMKM berdasarkan jenis kelamin hampir berimbang, laki-laki sebanyak $53,26 \%$ sementara perempuan sebanyak $46,74 \%$. Sebagian besar responden memiliki usia relatif muda antara 21-30 tahun sebanyak 35,33\% dan tingkat pendidikan responden SMA sebanyak $41,85 \%$.

Profil usaha yang dijalankan pelaku UMKM di Kabupaten Kubu Raya meliputi bidang usaha, jumlah pegawai, dan lama usaha. Berdasarkan Tabel 4 menunjukkan bahwa sebagian besar responden bergerak dibidang usaha jasa dan perdagangan $(51,63 \%)$, dengan jumlah pegawai kurang dari 5 orang $(80,98 \%)$ dan lama usaha kurang dari 5 tahun $(56,52 \%)$.

Analisis model persamaan dilakukan dengan pendekatan partial least square (PLS) melalui software SmartPLS. PLSdigunakan untuk konfirmasi teori dan menjelaskan ada tidaknya 
Tabel 3. Karakteristik Responden

\begin{tabular}{lcc}
\hline Variabel & Frekuensi & Persentase \\
\hline Jenis Kelamin & & \\
Laki-laki & 98 & 53,26 \\
Perempuan & 86 & 46,74 \\
\hline Jumlah & 184 & 100 \\
\hline Usia (tahun) & & \\
$\leq 20$ & 4 & 2,17 \\
$21-30$ & 65 & 35,33 \\
$31-40$ & 47 & 25,54 \\
$41-50$ & 52 & 28,26 \\
$>50$ & 16 & 8,70 \\
\hline Jumlah & 184 & 100 \\
\hline Pendidikan & & \\
SD & 18 & 9,78 \\
SMP & 20 & 10,87 \\
SMA & 77 & 41,85 \\
Diploma & 19 & 10,33 \\
Sarjana & 50 & 27,17 \\
\hline Jumlah & 184 & 100 \\
\hline
\end{tabular}

Sumber: Hasil pengolahan data penelitian

Tabel 4.Profil Usaha Responden

\begin{tabular}{lcc}
\hline Variabel & Frekuensi & Persentase \\
\hline Bidang Usaha & & \\
Kerajinan & 17 & 9,24 \\
Pengolahan Makanan & 54 & 29,35 \\
Jasa dan Perdagangan & 95 & 51,63 \\
Konveksi & 6 & 3,26 \\
Agrobisnis & 7 & 3,80 \\
Peternakan & 5 & 2,72 \\
\hline Jumlah & 184 & 100 \\
\hline Jumlah Pegawai & & \\
$<5$ & 149 & 80,98 \\
$5-19$ & 34 & 18,48 \\
$>20$ & 1 & 0,54 \\
\hline Jumlah & 184 & 100 \\
\hline Lama Usaha & & \\
$<5$ & 104 & 56,52 \\
$6-10$ & 38 & 20,65 \\
11 -15 & 24 & 13,04 \\
$15-20$ & 12 & 6,52 \\
$>20$ & 6 & 3,26 \\
\hline Jumlah & 184 & 100 \\
\hline
\end{tabular}

Sumber: Hasil pengolahan data penelitian

hubungan antar variabel laten. PLS mencakupmodel pengukuran dan model struktural.

Analisis model pengukuran dilakukan melalui tiga tahap. Tahap pertama melakukan pengujian validitas konvergen terhadap masing-masing indikator refleksif, tahap kedua melakukan pengujian validitas diskriminan pada indikator refleksif, dan tahap ketiga melakukan pengujian reliabilitas komposit pada variabel laten.

Penilaian validitas konvergen berdasarkan korelasi antara skor item/skor komponen dengan skor konstrak yang ditunjukkan oleh loading factor indikator-indikator yang mengukur konstruk tersebut. Indikator dianggap valid jika memiliki nilai loading di atas 0,5 dan atau nilai T-statistic di atas 1,96. Berdasarkan hasil pengujian validitas konvergen pada Tabel 5 menunjukkan semua indikator karakteristik kewirausahaan, kompetensi kewirausahaan, dan kinerja UMKM memenuhi validitas konvergen dengan nilai T-statistic berada di atas 1,96 dan tidak ada loading factor (original sample estimate) yang nilainya di bawah 0,5 . 
Tabel 5. Hasil Uji Validitas Konvergen

\begin{tabular}{lcccc}
\hline \multicolumn{1}{c}{ Variable } & $\begin{array}{c}\text { Original Sample } \\
\text { Estimate }\end{array}$ & $\begin{array}{c}\text { Mean of } \\
\text { Subsamples }\end{array}$ & $\begin{array}{c}\text { Standard } \\
\text { Deviation }\end{array}$ & T-Statistic \\
\hline Karakteristik & & & & \\
Percaya Diri & 0.744 & 0.744 & 0.047 & 15.964 \\
Orientasi Tugas dan Hasil & 0.876 & 0.871 & 0.027 & 31.912 \\
Pengambilan Resiko & 0.764 & 0.759 & 0.050 & 15.171 \\
Kepemimpinan & 0.851 & 0.851 & 0.026 & 33.089 \\
Keorisinilan & 0.729 & 0.729 & 0.051 & 14.312 \\
Orientasi Masa Depan & 0.708 & 0.706 & 0.063 & 11.236 \\
\hline Kompetensi & & & & \\
Pengetahuan & 0.900 & 0.901 & 0.015 & 58.260 \\
Keterampilan & 0.910 & 0.909 & 0.019 & 48.056 \\
Kemampuan & 0.849 & 0.845 & 0.032 & 26.558 \\
\hline Kinerja Usaha & & & & \\
Penjualan & 0.889 & 0.890 & 0.022 & 40.678 \\
Laba & 0.910 & 0.910 & 0.017 & 52.062 \\
Aset & 0.797 & 0.792 & 0.052 & 15.378 \\
Pelanggan & 0.887 & 0.887 & 0.031 & 28.932 \\
\hline
\end{tabular}

Sumber: Hasil pengolahan data penelitian

Pengujian validitas diskriminan dapat dilakukan dengan dua metode, yaitu nilai cross loading dan perbandingan akar average variance extracted (AVE) dengan korelasi antar variabel laten. Nilai cross loading diperoleh dari korelasi antara kontruk dengan indikator pengukurannya. Jika korelasi konstruk dengan item pengukuran lebih besar dari pada konstruk lainnya berarti konstruk laten memprediksi ukuran pada blok mereka lebih baik daripada ukuran pada blok lainnya (Ghozali, 2008:25).

Tabel 6. Nilai Cross Loading

\begin{tabular}{lccc}
\hline \multicolumn{1}{c}{ Variabel } & Karakteristik & Kompetensi & Kinerja \\
\hline Karakteristik & & & \\
Percaya Diri & 0.744 & 0.200 & 0.148 \\
Orientasi Tugas dan Hasil & 0.876 & 0.196 & 0.191 \\
Pengambilan Resiko & 0.764 & 0.292 & 0.051 \\
Kepemimpinan & 0.851 & 0.297 & 0.116 \\
Keorisinilan & 0.729 & 0.227 & 0.043 \\
Orientasi Masa Depan & 0.708 & 0.224 & 0.151 \\
\hline Kompetensi & & & \\
Pengetahuan & 0.204 & 0.900 & 0.332 \\
Keterampilan & 0.197 & 0.910 & 0.293 \\
Kemampuan & 0.199 & 0.849 & 0.279 \\
\hline Kinerja & & & \\
Penjualan & 0.148 & 0.380 & 0.889 \\
Laba & 0.176 & 0.514 & 0.910 \\
Aset & 0.108 & 0.241 & 0.797 \\
Pelanggan & 0.127 & 0.486 & 0.887 \\
\hline Sumber: & & &
\end{tabular}

Sumber: Hasil pengolahan data penelitian

Berdasarkan hasil cross loading pada Tabel 6 menunjukkan bahwa indikator-indikator karakteristik kewirausahaan memiliki nilai cross loading tertinggi pada kolom variabel laten karakteristik kewirausahaan, demikian juga indikator-indikator kompetensi kewirausahaan dan kinerja UMKM. Hal ini mengindikasikan bahwa indikator memprediksi variabel latennya lebih baik daripada variabel laten yang lain. Dengan demikian validitas diskriminan terpenuhi.
Metode kedua untuk menguji validitas diskriminan dapat dilakukan dengan membandingkan akar AVE untuk setiap variabel laten dengan koefisien korelasi antar variabel laten. Jika akar AVE lebih besar dari korelasi antar variabel laten, maka validitas diskriminan terpenuhi. Pada Tabel 7 menunjukkan bahwa nilai akar AVE variabel laten karakteristik kewirausahaan, kompetensi kewirausahaan, dan kinerja UMKM lebih besar dibandingkan dengan korelasi antar variabel laten. 
Tabel 7. AVE, Akar AVE, dan Korelasi Antar Variabel Laten

\begin{tabular}{lccccc}
\hline \multicolumn{1}{c}{ Variabel } & AVE & Akar AVE & Karakteristik & Kompetensi & Kinerja \\
\hline Karakteristik & 0.610 & 0.781 & 1.000 & & \\
Kompetensi & 0.786 & 0.887 & 0.285 & 1.000 & \\
Kinerja & 0.760 & 0.872 & 0.179 & 0.439 & 1.000 \\
\hline
\end{tabular}

Sumber: Hasil pengolahan data penelitian

Dengan demikian disimpulkan bahwa validitas diskriminan terpenuhi.

Pengujian reliabilitas komposit dilakukan untuk menguji konsistensi butir-butir instrumen penelitian menurut penilaian responden. Instrumen penelitian dikatakan memiliki reliabilitas komposit yang baik jika nilainya di atas 0,70 . Hasil pengujian reliabilitas komposit pada Tabel 8 menunjukkan masing-masing variabel laten memiliki nilai reliabilitas komposit di atas 0,70 .

Tabel 8. Hasil Uji Reliabilitas Komposit

\begin{tabular}{lc}
\hline \multicolumn{1}{c}{ Variabel } & Composite Reliability \\
\hline Karakteristik & 0.903 \\
Kompetensi & 0.917 \\
Kinerja & 0.927
\end{tabular}

Sumber: Hasil pengolahan data penelitian

Penilaian goodness of fit model struktural dapat dilihat dari nilai R-square dari variabel laten endogen pada persamaan struktural, ukuran Q-square predictive relevance, dan uji t serta signifikansi dari koefisien parameter jalur struktural.R-square berfungsi untuk melihat seberapa besar keragaman variabel endogen dijelaskan oleh variabel eksogen. Tabel 9 menunjukkan hasil estimasi R-square untuk variabel laten endogen. Model pengaruh karakteristik kewirausahaan terhadap kompetensi kewirausahaan mempunyai nilai R-square sebesar 0,081, artinya variabilitas variabel kompetensi kewirausahaan yang dapat dijelaskan oleh variabilitas variabel karakteristik kewirausahaan sebesar $8,1 \%$ sedangkan 91,9\% dijelaskan oleh variabel lain di luar model penelitian. Untuk kinerja UMKM memiliki nilai R-square sebesar 0,196 , artinya $19,6 \%$ variabilitas variabel kinerja UMKM mampu dijelaskan oleh variabel karakteristik kewirausahaan dan kompetensi kewirausahaan, sisanya 80,4\% dijelaskan oleh variabel lain di luar model penelitian.

Q-square predictive relevance digunakan untuk mengukur seberapa baik nilai observasi dihasilkan oleh model dan juga estimasi parameternya. Besarnya nilai Q-square adalah: $\mathrm{Q}^{2}$
Tabel 9. Nilai R-Square Variabel Endogen

\begin{tabular}{lc}
\hline Variabel Endogen & R-Square \\
\hline Kompetensi & 0.081 \\
Kinerja & 0.196 \\
\hline Sumber: Hasil pengolahan data penelitian
\end{tabular}

$=1-\left(1-\mathrm{R}_{1}^{2}\right)\left(1-\mathrm{R}_{2}^{2}\right)$ di mana $\mathrm{R}_{1}^{2}$ dan $\mathrm{R}_{2}^{2}$ adalah $\mathrm{R}$-square variabel endogen dalam model penelitian. Dengan demikian nilai $\mathrm{Q}^{2}=1-(1-0,081)(1-$ $0,196)=0,261$, artinya model mampu menjelaskan kinerja UMKM sebesar 26,1\%, sedangkan sisanya $73,9 \%$ dijelaskan oleh variabel lain yang belum masuk ke dalam model dan error.

Untuk menilai signifikansi jalur struktural dapat dilihat dari nilai T-statistic. Jika nilai T-statistic lebih dari sama dengan 1,96 maka terdapat pengaruh yang signifikan antar variabel laten, namun jika nilai Tstatistic lebih kecil dari 1,96 maka tidak terdapat pengaruh yang signifikan antar variabel laten. Hasil pengujian pada Tabel 10 menunjukkan bahwa pada estimasi pengaruh langsung, terdapat pengaruh variabel karakteristik kewirausahaan terhadap kinerja UMKM, sedangkan pada estimasi pengaruh tidak langsung, terdapat dua jalur yang signifikan, yaitu pengaruh karakteristik kewirausahaan terhadap kompetensi kewirausahaan dan pengaruh kompetensi kewirausahaan terhadap kinerja UMKM.

Nilai koefisien dan T-statistic masing masing jalur dapat dijelaskan bahwaestimasi pengaruh langsung karakteristik kewirausahaan terhadap kinerja UMKM memiliki nilai koefisien sebesar 0,205 dengan nilaiT-statistic sebesar 3,234. Dengan demikian, terdapat pengaruh signifikan variabel karakteristik kewirausahaan terhadap variabel kinerja UMKM. Nilai koefisien positif menunjukkan hubungan yang searah antara karakteristik kewirausahaan dan kinerja UMKM.

Estimasi pengaruh tak langsung secara simultan menunjukkan pengaruh karakteristik kewirausahaan terhadap kompetensi kewirausahaan memiliki nilai koefisien sebesar 0,285 dengan nilai T-statistic sebesar 4,095. Dengan demikian, model dapat diterima, artinya terdapat pengaruh signifikan 
Tabel 10. Hasil Pengujian

\begin{tabular}{lcccc}
\hline \multirow{2}{*}{ Hubungan Antar Variabel } & \multicolumn{2}{c}{ Pengaruh Langsung } & \multicolumn{2}{c}{ Pengaruh Tak Langsung } \\
\cline { 2 - 5 } & Koefisien & T-Statistic & Koefisien & T-Statistic \\
\hline Karakteristik -> Kompetensi & & 0.285 & 4.095 \\
Karakteristik -> Kinerja & 0.205 & 3.234 & 0.058 & 0.896 \\
Kompetensi -> Kinerja & & 0.423 & 5.892 \\
\hline
\end{tabular}

Sumber: Data primer diolah.

variabel karakteristik kewirausahaan terhadap variabel kompetensi kewirausahaan. Nilai koefisien positif menunjukkan semakin kuat karakteristik kewirausahaan maka semakin tinggi kompetensi kewirausahaan yang dimiliki pelaku UMKM. Pengaruh karakteristik kewirausahaan terhadap kinerja UMKM memiliki nilai koefisien sebesar 0,058 dengan nilai T-statistic sebesar 0,896.Dengan demikian, model tidak dapat diterima, artinya tidak terdapat pengaruh signifikan variabel karakteristik kewirausahaan terhadap kinerja UMKM. Nilai koefisien positif menunjukkan hubungan yang searah antara karakteristik kewirausahaan dan kinerja UMKM. Pengaruh kompetensi kewirausahaan terhadap kinerja UMKM memiliki nilai koefisien sebesar 0,423 dengan nilai T-statistic sebesar 5,892. Dengan demikian, model dapat diterima, artinya terdapat pengaruh signifikan variabel kompetensi kewirausahaan terhadap variabel kinerja UMKM. Nilai koefisien positif menunjukkan semakin tinggi kompetensi kewirausahaan maka semakin tinggi kinerja UMKM.

Hasil penelitian membuktikan bahwa koefisien pengaruh langsung karateristik kewirausahaan terhadap kinerja positif dan signifikan, sementara koefisien pengaruh tak langsung karakteristik kewirausahaan terhadap kinerja UMKM tidak signifikan. Hal ini menunjukkan kompetensi kewirausahaan memediasi secara penuh (full mediation) pengaruh karakteristik kewirausahaan terhadap kinerja UMKM. Model dalam penelitian ini mendukung penelitian Sarwoko et al. (2013) yang menunjukkan bahwa kompetensi merupakan variabel mediasi antara karakteristik kewirausahaan dan kinerja UMKM.

Temuan penelitian mengindikasikan bahwa karakteristik kewirausahaan berperan dalam meningkatkan kompetensi kewirausahaan pelaku UMKM. Hasil ini konsisten dengan penelitian yang dilakukan Sarwoko et al. (2013) dan mendukung pendapat Adegbite et al. (2006) dan Segal et al. (2009) bahwa karakteristik kewirausahaan merupakan faktor penting dalam membentuk dan menilai keberadaan kompetensi kewirausahaan
UMKM. Karakteristik kewirausahaan yang kuat diperlukan pelaku UMKM untuk membentuk kompetensi kewirausahaan sehingga diharapkan akan mampu meningkatkan kinerja UMKM dengan melaksanakan usaha yang efisien dan mampu menghasilkan produk-produk berkualitas tinggi serta mampu bertahan di pasar domestik maupun regional.

Pengaruh karakteristik kewirausahaan terhadap kinerja UMKM tidak signifikan. Walaupun skor ratarata deskripsi karakteristik kewirausahaan sebesar 4,10 artinya responden mempersepsikan diri mereka memiliki karakteristik kewirausahaan cenderung tinggi, namun belum mampu memberikan kontribusi pada peningkatan kinerja UMKM. Hal ini terjadi karena karakteristik kewirausahaan yang melekat pada pelaku UMKM belum sepenuhnya dapat berkontribusidalam usaha atau dengan kata lain pelaku UMKM belum mampu menterjemahkan, menggunakan atau mengintegrasikankarakteristik kewirausahaantersebut kedalam usahanya (Meredith et al., 2000). Hasil ini berkesesuaian dengan penelitian Begley \& Boyd (1987) yang menunjukkan hubungan yang rendah diantara keduanya. Namun, hasil ini berbeda dengan beberapa temuan penelitian sebelumnya (Hall, 1994; Islam et al., 2011; Sarwoko et al., 2013; Liang \& Dunn, 2010).

Hasil penelitian membuktikan bahwa kompetensi kewirausahaan berpengaruh positif signifikan terhadap kinerja UMKM.Hasil ini konsisten dengan penelitiansebelumnya yang menunjukkan peran penting kompetensi wirausaha dalam mendorong kemajuan bisnis. Diantaranya, penelitian Hormiga et al. (2010) yang membuktikan human capital (interaksi tim kewirausahaan, komitmen, pengetahuan bisnis, dan pemecahan masalah) memiliki hubungan dengan kesuksesan usaha. Penelitian Man \& Lau (2008) menunjukkan kompetensi 153 pemilik/manajer UKM sektor jasa di Hongkong secara langsung dan tidak langsung berpengaruh terhadap kinerja jangka panjang UKM melalui lingkup kompetitif dan kapabilitas organisasi. Penelitian Karami (2004) pada 132 UKM dalam industri elektronik di Inggris menunjukkan bahwa peningkatan kompetensi khususnya kapasitas sumber daya manusia perusahaan 
berhubungan secara positif dengan peningkatan kinerja organisasi. Penelitian Barazandeh et al. (2015) menyatakan kompetensi wirausaha berdampak positif terhadap kinerja bisnis diantara 125 wirausaha pemula yang dipilih dari data Global Entrepreneurship Monitor (GEM) dari 59 negara. Penelitian Sarwoko et al. (2013) membuktikan bahwa kompetensi kewirausahaan berdampak pada kinerja bisnis 147 UKM di Malang Jawa Timur. Penelitian Tanoira\&Valencia (2014) menunjukkan terdapat relasi yang kuat antara kompetensi kewirausahaan dan kinerja pada 374 UMK yang bergerak di bidang sistem informasi perusahaan di Mexico.Penelitian Mohamad\&Sidek (2013) menunjukkan bahwa kompetensi kewirausahaan secara signifikan memiliki hubungan dengan pertumbuhan bisnis usaha kecil dari 243 microfinance di Malaysia. Namun penelitian Baum et al. (2001) menunjukkan bahwa kompetensi umum bukan merupakan prediktor terhadap pertumbuhan bisnis, namun kompetensi khusus berpengaruh signifikan terhadap pertumbuhan bisnis dari 307 perusahaan yang bergerak pada industri arsitektur kayu di Amerika Serikat.

\section{SIMPULAN DAN SARAN Simpulan}

Berdasarkan hasil penelitian dan pembahasan, maka dapat ditarik beberapa simpulan. Pertama, karakteristik kewirausahaan berpengaruh positif siginfikan terhadap kompetensi kewirausahaan, artinya karakteristik kewirausahaan yang kuat akan meningkatkan kompetensi kewirausahaan yang diperlukan pelaku UMKM. Kedua, karakteristik kewirausahaan tidak berpengaruh signifikan terhadap kinerja UMKM, artinya kuatnya karakteristik kewirausahaan tidak akan mempengaruhi tingkat kinerja yang dihasilkan UMKM. Ketiga, kompetensi kewirausahaan berpengaruh positif signifikan terhadap kinerja UMKM, artinya tingginya kompetensi kewirausahaan yang dimiliki pelaku UMKM akan meningkatkan kinerja UMKM. Keempat, kompetensi kewirausahaan merupakan variabel yang berperan sebagai mediasi penuh antara karakteristik kewirausahaan dan kinerja UMKM.

\section{Saran}

Berdasarkan simpulan hasil penelitian di atas, dapat diberikan beberapa saran.Pertama, memperkuat karakteristik dan kompetensi kewirausahaan pelaku UMKM melalui pelatihan dan pendampingan serta tindak lanjut agar dapat meningkatkan kinerja UMKM. Kedua, meningkatkan peran pemerintah dan lembaga lainnya yang terkait dalam memberikan bantuanatau fasilitas kemudahan bagi pelaku UMKM dalam mengakses sumber daya ekonomi untuk mengembangkan usahanya. Ketiga, bagi peneliti selanjutnya dapat mengembangkan penelitian dengan mengeksplorasi berbagai variabel yang memungkinkan untuk meningkatkan kinerja UMKM.

\section{REFERENSI}

Adegbite, S.A., Ilori, M.O., Irefin, I.A., Abereijo, I.O., \& Aderemi, H.O.S. 2006. Evaluation of the Impact of Entrepreneurial Characteristics on the Performance of Small Scale Manufacturing Industries in Nigeria. Journal of Asia Entrepreneurship and Sustainability, 3 (1), $1-22$.

Amage, N., Rinthaisong, I., \& Songsom, A. 2014. Factors Influencing to Behavioral Competency for Competitiveness and Success of Thai Malaysia Border Trade Entrepreneurs to Suport AEC.Journal of Management Research, 6 (2), 221-231.

Ardiana, I.D.K.R., I.A. Brahmayanti \& Subaedi. 2010. Kompetensi SDM UKM dan Pengaruhnya Terhadap Kinerja UKM di Surabaya. Jurnal Manajemen dan Kewirausahaan, 12 (1), 42-55.

Ardichvili, A., Cardozo, R., \& Ray, S. 2003. ATheory of Entrepreneurial Opportunity Identification and Development. Journal of Business Venturing, 18, 105-123.

Attahir, Y. 1995. Critical Success Factor for Small Business: Perceptions of South Pacific Entrepreneurs. Journal of Small Business Management, 33 (2), 68-73.

Bank Indonesia. 2015. Profil Bisnis Usaha Mikro, Kecil dan Menengah (UMKM). Diakses dari www.bi.go.id pada tanggal 12 Oktober 2016.

Barazandeh, M., Parvizian, K., Alizadeh, M., \& Khosravi, S. 2015. Investigating the Effect of Entrepreneurial Competencies on Business Performance Among Early Stage Entrepreneurs Global Entrepreneurship Monitor (GEM 2010 Survey Data). Journal of Global Entrepreneurship Research, 5 (18), 1-12.

Baum, J.R., Locke, E.A., \& Smith, K.G. 2001. A Multidimensional Model of Venture Growth. Academy of Management Journal, 44 (2), 292-303.

Begley, T.M., \& Boyd, D.P. 1987. Psychological Characteristics Associated with Performance in Entrepreneurial Firms and Smaller Businesses. Journal of Business Venturing, 2, 79-93. 
Boyatzis, R.E. 2009. Competencies as A Behavioral Approach to Emotional Intelligence. Journal of Management Development, 28 (9), 749-770.

Dinas Koperasi dan Usaha Mikro, Kecil, dan Menengah. 2014. Pemerintah Kabupaten Kubu Raya: Rencana Strategis Tahun 2014-2019.

Driessen F.B., \& Ende, J.V.D. 2006. Innovation in Project-Based Firms: The Context Dependency of Success Factors. Research Policy, 35, 545-561.

Ghozali, I. 2008. Structural Equation Modeling: Metode Alternatif dengan Partial Least Square. Semarang: Badan Penerbit Universitas Diponegoro.

Ghozali, I., \& Latan, H. 2015. Partial Least Square, Konsep, Teknik dan Aplikasi Menggunakan Program SmartPLS 3.0 Untuk Penelitian Empiris. Semarang: Badan Penerbit Universitas Diponegoro.

Lee, D.Y., \& Tsang, E.W.K. 2001.The Effect of Entrepreneurial Personality, Background and Network Activities on Venture Growth. Journal of Management Studies, 38 (4), 583602.

Chye, L.T., Tat, H.H., Osman, M.H.M., \& Rasli, A.M. 2010. Are Managerial Competencies ABlessing to the Performance of Innovative SMEs in Malaysia.International Journal of Economics and Management, 4 (1), 120-136.

Dipta, W.I. 2012. Memperkuat UKM Menghadapi Masyarakat Ekonomi Asean Tahun 2015. Infokop, 21, 1-12.

Hall, G. 1994. Factors Distinguishing Survivors from Failures Among Small Firms in the UK Construction Sector. Journal of Management Studies, 31 (5), 738-759.

Hormiga, E., Batista-Canino, R.M., \& SanchezMedina, A. 2010.The Role of Intellectual Capital in the Success of New Ventures. International Entrepreneurship and Management Journal. Doi: 10.1007/s11365010-0139-y.

Islam, M.A., Khan, M.A., Obaidullah, A.Z.M., \& Alam, M.S. 2011. Effect of Entrepreneur and Firm Characteristics on the Business Success of Small and Medium Enterprises (SMEs) in Bangladesh. International Journal of Business and Management, 6 (3), 289-299.

Karami, A. 2004. How Human Resource Capabilities Affect the Organisations' Performance? The Case of Electronic Industry in the UK. The Fifth European Conference on Organizational Knowledge, Learning and Capabilities, Centre of Strategic Management \& Leadership, University of Innsbruck, Austria.

Kaur, H.,\& Bains, A. 2013.Understanding the Concept of Entrepreneur Competency. Journal of Business Management \& Social Sciences Research, 2 (11), 31-33.

Kuratko, D.F., \& Hodgetts, R.M. 2004. Entrepreneurship, 5 $^{\text {th }}$ Edition. Mason, Ohio: Thomson South-Western.

Li, X. 2009. Entrepreneurial Competencies as an Entrepreneurial Distinctive: An Examination of the Competency Approach in Defining Entrepreneurs. Theses, Institutional Knowledge at Singapore Management University.

Liang, K., \& Dunn, J. 2010. Entrepreneurial Characteristics, Optimism, Pessimism, and Realism - Correlation or Collision?Journal of Business and Entrepreneurship, 22 (1), 1-22.

Man, T.W.Y., \& Lau T. 2005. The Context of Entrepreneurship in Hongkong: An Investigation Through the Patterns of Entrepreneurial Competencies in Contrasting Industrial Environments. Journal Small Business and Enterprise Development, 12 (4), 464-481.

Man, T.W.Y., \& Lau, T. 2008. Entrepreneurial Competencies and the Performance of Small and Medium Enterprises: an Investigation Through a Framework of Competitiveness. Journal of Small Business and Entrepreneurship, 21 (3), 257-276.

Man, T.W.Y., Lau, T., \& Chan, K.F. 2002. The Competitiveness of Small and MediumEnterprises - A Conceptualization with Focus on Entrepreneurial Competences. Journal of Business Venturing, 17 (2), 123-142.

Merredith, G.G., Robert, E.N., \& Phillip, A.N. 2000. Kewirausahaan: Teori dan Praktek, Penerjemah Andre Aspasayogi. Jakarta: Pustaka Binaman Pressindo.

Mohamad, M.R., \& Sidek, S. 2013. The Role of Entrepreneurial Competencies as A Mediator in the Relationship Between Microfinance and Small Business Growth. Journal of Entrepreneurship and Business, 1 (1), 21-31. Ng, H.S., \&Kee, D.M.H. 2013. Effect of Entrepreneurial Competencies on Firm Performance Under the Influence of Organizational Culture. Life Science Journal, 10 (4), 2459-2466.

Sarwoko, E., Surachman, Armanu, \& Hadiwidjoo, D. 2013. Entrepreneurial Characteristics and Competency as Determinants of Business 
Performance in SMEs.IOSR Journal of Business and Management, 7 (3), 31-38, www.iosrjournals.org.

Segal, G., Borgia, D., \& Schoenfeld, J. 2009. Founder Human Capital and Small Firm Performance: An Empirical Study of Founder-Managed Natural Food Stores. Journal of Management and Marketing Research, 4, 1-10.

Spencer, L.M., \& Spencer, S.M. 1993. Competence at Work: Model for Superior Performance. New York: John Wiley \& Son, Inc.

Susilo, Y.S. 2010.Strategi Meningkatkan Daya Saing UMKM dalam Menghadapi Implementasi CAFTA dan MEA. Buletin Ekonomi, 8 (2), 70-170.

Tambunan, T.T.H. 2012. Pasar Bebas ASEAN: Peluang, Tantangan dan Ancaman Bagi UMKM Indonesia. Infokop, 21, 13-35.

Tanoira, F.G.B., \& Valencia, R.A.S. 2014. Knowledge Management, Entrepreneurial
Competencies and Organizational Development in Micro and Small Enterprises in Rural Regions in The State of Yucatan, Mexico. European Scientific Journal, 10 (1), 177-193.

Wickramaratne, A., Kiminami, A., \& Yagi, H. 2014. Entrepreneurial Competencies and Entrepreneurial Orientation of Tea Manufacturing Firms in Sri Lanka. Asian Social Science, 10 (18), 50-62.

Wu, W.W. 2009. A Competency-Based Model for the Success of An Entrepreneurial Start-Up. WSEAS Transactions on Business and Economics, 6 (6), 279-291.

Zimmerer, T.W., \& Scarborough, N.M. 2004. Pengantar Kewirausahaan dan Manajemen Bisnis Kecil. Jakarta: PT. Indeks Kelompok Media.

Zulfadil. 2006. Manajemen Strategik, Intrapreneurship dan Kinerja: Survei pada Koperasi Sekunder KP-RI. Manajemen Usahawan Indonesia, No. 09, TH. XXXV, September. 